\title{
肺癌患者の末梢血の単球機能異常について
}

\section{Monocyte Function in Patients with Bronchogenic Carcinoma}

中田安成・片岡幹男・山下二郎・佐藤俊雄・野田憲男

中田康則・平木俊吉・大熨泰亮・木村郁郎

\begin{abstract}
抄録：肺癌患者 59 名の末梢血単球機能について検討した。単球数は $294 \pm 176 / \mathrm{cmm}$ (対照健康人 $299 \pm 144 / \mathrm{cmm})$ と差は認められなかった。単球の $\beta$-galactosidase活性は23.1 $111.8 \%$ (健 康人 $33.7 \pm 12.1 \%$ ), 単球走性は $19.4 \pm 7.0$ (健康人 $34.8 \pm 8.0$ ), 単球貧食能は $60.8 \pm 23.6$ (健康人 $82.1 \pm 9.5$ ) といずれの機能も対照健康人に比較して有意な低下が認められた。な お以上の単球機能異常は臨床病期の進行とともに強まる傾向がみられたが, 組織型との 間には相関は認められなかった。
\end{abstract}

\section{緒 言}

ヒト末梢血単球及び組織マクロファージの生 体に打ける役割は食菌作用, 殺菌作用, 抗原の 領食消化及び免疫情報の伝達等の作用の他に, 近年, ヒト末梢血単球が腫瘍細胞に対して抗体 の存在下, ${ }^{\prime \prime}$ あるいは抗体の存在なくして州2),31 直接的に傷害作用を有することが明らかにされ， とくに担癌生体における単球の動態が注目をあ びるようになった。著者らはヒトの担癌状態に おける末梢血単球の機能及び動態を検討するた めに，肺癌患者において検討を加えた。

\section{対象および方法}

対象は当科に入院した原発性肺癌患者59名で ある。男性45例, 女性14例で, 年令巾は44才よ リ74才まで, 中央値は63才であった。全例とも 診断は生検組織診および細胞診にて確定された。 病期は日本肺癌学会TNM分類に従って決定し た.

末梢血単球数の算定：末梢血塗抹標本の, Ma-

岡山大学医学部第 2 内科学教室

（主任：木村郁郎教授）
y-Giemsa 染色にて白血球を500個分類して, 単 球の百分率を求め, コ一ルタ一カウンターにて 計测した白血球数に乗じて, / $\mathrm{cmm}$ 中の単球数 を算出した。

末梢血単球の $\beta$-galactosidase活性：へパリン 加静脈血にDextran溶液を加之, 白血球層を分離 し塗抹標本を作製した。25\%Glutaraldehydeに て 1 分間固定し，調製染色液にて18時間染色を 行った。さらにメチルアルコール：ホルマリン : 水酢酸混合液 $(20 ： 2 ： 1)$ で 1 分間固定し, Mayer-Hematoxyline液にて20分間染色した。顕 微鏡下1000倍にて， $\beta$-galactosidase顆粒を有す る単球の百分率を求めた。調整染色液はN,N-Dimethy1 formaldehyde $0.5 \mathrm{ml}, 5$ - Bromo - 4 Chloro-3-Indory $1-\beta$-D-galactosidase (Sigma 社） $2 \mathrm{mg}$ を $\mathrm{pH} 5.4,0.1 \mathrm{M}$ 酢酸緩衝液 $31 \mathrm{ml}$ に 溶かし, Spermidin-HCl(Sigma社) $8 \mathrm{mg}$, 生食水 $0.5 \mathrm{ml}$ を混合し, $1 \mathrm{M}$ Potassium Ferrocyanide, $1 \mathrm{M}$ Potassium Ferricyanideの各々 $3 \mathrm{ml}$ を加え て作製した。

単球走性：9\% Ficoll400(Pharmacia社) 液 24 容とHypaque (Nye Garrd社)10容の混合液 $3 \mathrm{ml}$ 
Fig. 1 Peripheral blood monocyte counts in patients with bronchogenic carcinoma and healthy controls

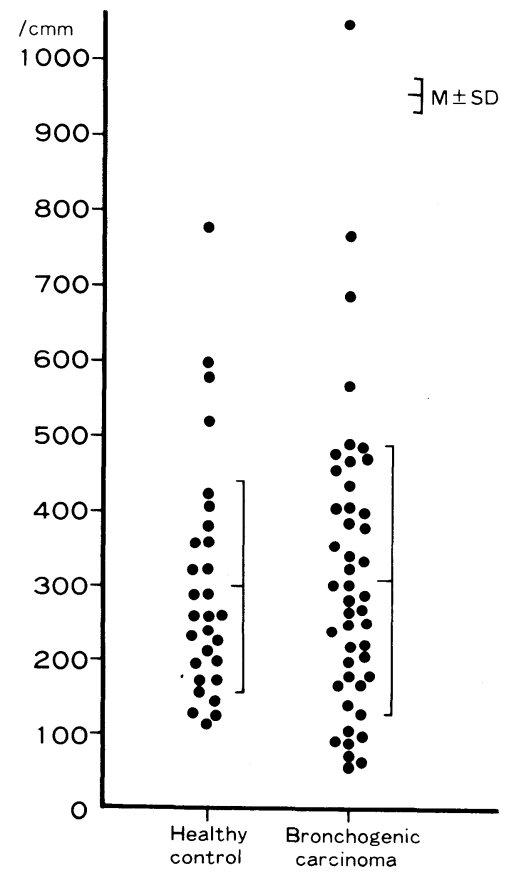

をがラス管に取り，へパリン加静脈血 $3 \mathrm{ml}$ 重 層し，室温にて $400 \mathrm{~g} ， 35$ 分間遠心分離を行った。 単核球層を採取し洗滌後, RPMI-1640中に単球 数を $6 \times 10^{5} / \mathrm{ml}$ に調整浮遊した。単球遊走因子 としては, 新鮮ヒト血清 $1 \mathrm{ml}$ にZymosan A( Sigma社) $0.5 \mathrm{mg}$ を加之, $37^{\circ} \mathrm{C}, 45$ 分間反応させた のち，56 ${ }^{\circ} \mathrm{C}$, 30分間非働化してRPMI-1640 4.0ml を加之, 稀釈して用いた。単球走性の测定はBoyden chamberを用い, 下室にZymosan 活性化 血清を満し, 中間に穴の径が $5 \mu \mathrm{m}$ の Millipore filter (Millipore社)をおき, 上室に単球浮遊液 $0.5 \mathrm{ml}$ を大れた。 $37^{\circ} \mathrm{C}, 5 \% \mathrm{CO}_{2}$ incubator中に90分間 静置後, フィルターを取り出し, アルコール固定, Harris Hematoxylin液にて染色，水洗したのち， 10\%酢酸アルコール，青化試薬にて反応させ， 脱水，包埋した。顕微鏡下 400 倍にてフィルター の上面より $30 \mu \mathrm{m} の$ 距離にまで遊走してきた全視 野中の細胞数を計测し, 5 視野の平均細胞数を 単球走性指数 (Monocyte Chemotactic Response, MCR）とした。

単球貧食能の测定：前述したFicoll-Hypaque
Fig. 2 Peripheral blood monocyte counts in patients with bronchogenic carcinoma related to clinical stage.

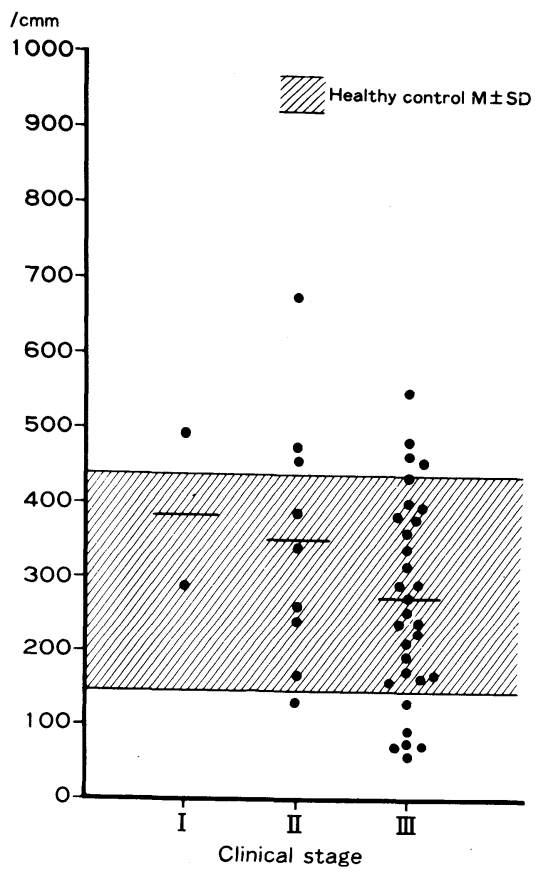

比重遠沈法にて分離した単核球を $10 \% \mathrm{AB}$ 型! ト血清を含むPRMI-1640中に浮遊した。これを Labtek chamber非 4838 に入狄， $37^{\circ} \mathrm{C} ， 90$ 分間, $5 \% \mathrm{CO}_{2}$ incubatorの中に静置し，浮遊細胞を除 去しがラス板附着細胞をえた。この附着細胞に ヒト補体結合Zymosanを混じ， $37^{\circ} \mathrm{C} ， 20$ 分間反 応させたのち, 浮遊Zymosanを洗滌除去し, chamberよりスライドグラスを取りはずし, Pero xidase-Giemsa重染色を行った。単球200個を数 之て，筫食細胞の百分率を求め，貧食指数とし た。

\section{結 果}

末梢血単球数：未治療肺癌患者 46 例では 294 $\pm 176(\mathrm{M} \pm \mathrm{SD}) / \mathrm{cmm}$ で，対照健康人 29 名の 299 土144/cmmに比較して全く差は認められなかっ た（図 1 )。病期の確定した42例について病期別 に単球数をみてみると I 期 2 例で $390 / \mathrm{cmm}$, II 期 9 例では $354 \pm 160 / \mathrm{cmm}$, III 期 31 例で $274 \pm$ $142 / \mathrm{cmm}$ であった．III期症例は，I，II期症例 に比して単球数の減少傾向がみられた(図 2 ). 
Fig. 3 Effect of COMP chemotherapy on peripheral blood monocyte count in patients with bronchogenic carcinoma

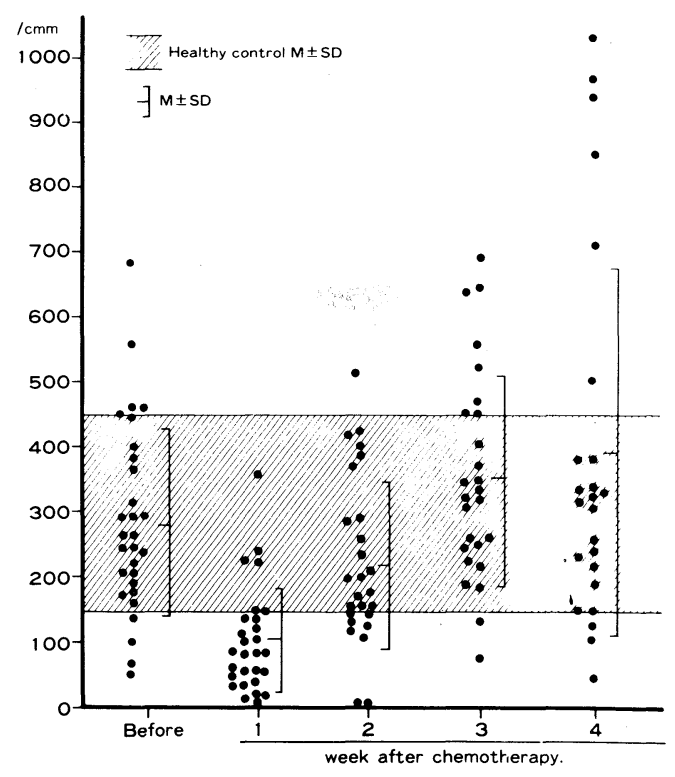

44例の組織型の判明した症例について組織型別 に比較した。腺癌 18 例で332 $239 / \mathrm{cmm}$, 扁平 上皮癌 7 例で $427 \pm 135 / \mathrm{cmm}$ ，小細胞癌16例で 255 土136/cmm大細胞癌 3 例で376 $166 / \mathrm{cmm}$ で あった。扁平上皮癌で増多; 小細胞癌で減少の 傾向がみられたが，有意な差ではなかった。化 学療法の施行された29例について, 化学療法の 末梢血単球数への直接的影響を検討した (図 3 ). 化学療法はCyclophosphamide, Vincristine, Methotrexate, Procarbazineの四者併用 (COMP) 療法で，4週間間隔にて繰り返すものである。 治療開始前の 29 症例の未梢血単球数は $268 \pm 148$

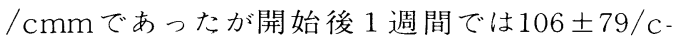
$\mathrm{mm}$ と著明に減少し，2 週後には $221 \pm 126 / \mathrm{cmm}$ と回復がみられ， 3 週後には $352 \pm 157 / \mathrm{cmm}$ ， 治療開始前の值に戻り，4週後には397 $\pm 288 / c$ $\mathrm{mm}$ と治療前よりも更に増加する症例が認めら れた。化学療法の効果別に治療前と効果判定時 における末梢血単球数の変動を検討した(図 4 ). なお効果判定は化学療法 2 ～ 4 コース終了後に 行なわれ, 効果判定の時期屾最終化学療法から 3 週後, 即ち, 抗癌剂による直接的影響が消失し た時点である．完全退縮例 4 例では全例 (100\%)
Fig. 4 Peripheral blood monocyte counts in patients with bronchogenic carcinoma; Before and after COMP chemotherapy related to response to chemotherapy

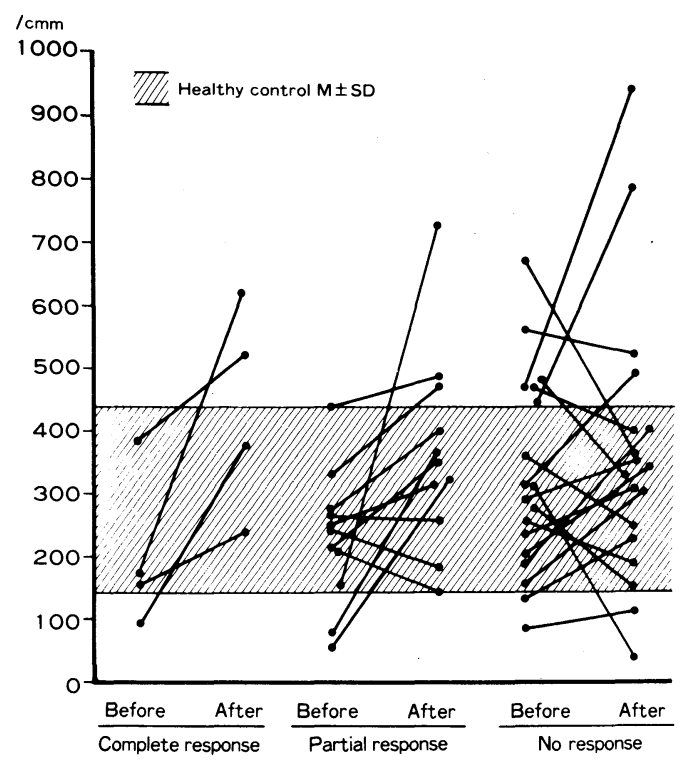

Fig. 5 Beta-galactosidase activity of peripheral blood monocyte in patients with bronchogenic carcinoma and healthy controls

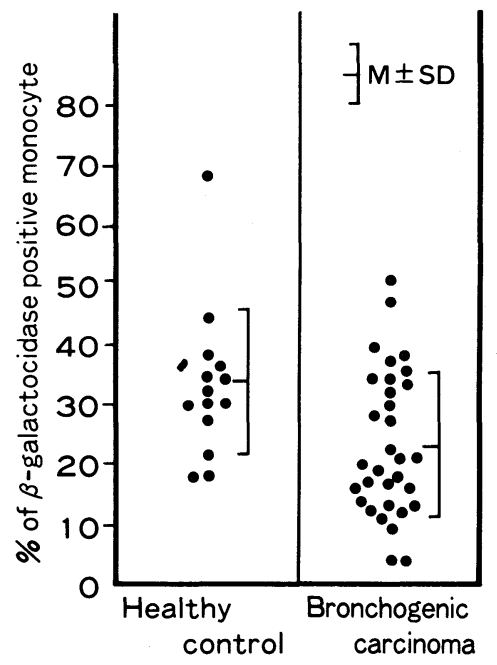

に，不完全退縮例11例では 8 例 $(73 \%)$ に治療後 に単球数の増加が認められたが, 無効例18例で

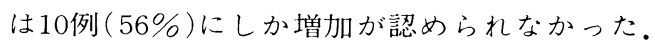

末梢血単球の $\beta$-galactosidase活性：未治療肺 癌患者32例では $23.1 \pm 11.8 \%$ で, 対照健康人 14 
Fig. 6 Monocyte chemotactic response rate in patients with bronchogenic carcinoma and healthy controls

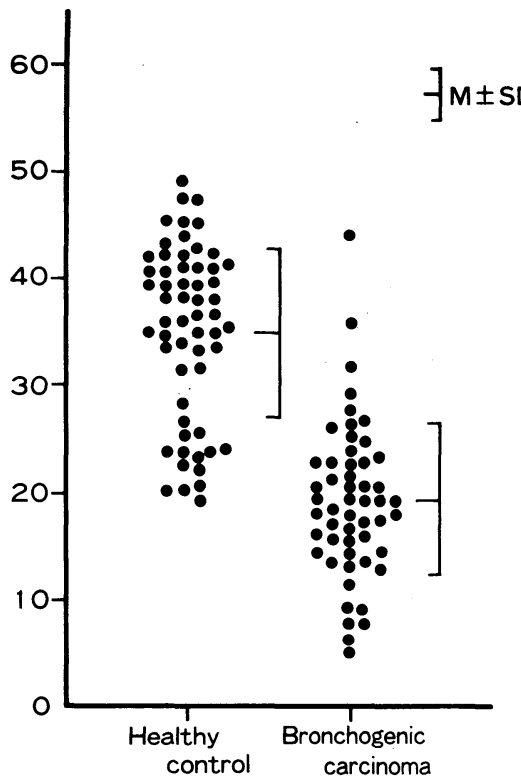

名の $33.7 \pm 12.1 \%$ と比較すると有意な低下 $(\mathrm{P}<$ 0.01 )がみられた（図 5 )。これを病期別に検討 すると， I 期 5 例では $24.1 \pm 11.9 \% ，$ II 期 1 例 では33.9\%，III期26例では $22.5 \pm 11.8 \%$ 各病 期間に差は認められなかった。さらに組織型別 にみてみると, 腺癌11例で $21.4 \pm 11.1 \%$, 扁平 上皮癌 14 例で $23.8 \pm 9.8 \%$, 小細胞癌 6 例で 21.3 $\pm 13.5 \%$, 大細胞癌 1 例で $47.1 \%$ であ, 組織 型による特異性は認められなかった。15症例に ついて化学療法前と, 開始後 3 週間目の $\beta$-galac tosidase活性の変動をみてみると, 前には $24.7 \pm$ $13.0 \%$ で，3 週後は $21.7 \pm 8.1 \%$ とな，両者間 に有意の差はなかった。

単球走性：未治療肺癌53例の単球走性は19.4 \pm 7.0 と対照健康人 58 例の $34.8 \pm 8.0$ に比して有 意の低下 $(\mathrm{P}<0.001)$ が認められた。病期判定不 能の 1 例を除いた52例について病期別にみると, I 期 9 例で $22.9 \pm 9.4$ ， II 期 5 例で19.4 44.5 , III 期38例で18.5土6.5であり，平均值において， 病期の進行とともにより低下する傾向がみられ た(図 7 )。組織型別では，小細胞癌 10 例で 16.0 \pm 6.6 , 腺癌 20 例で19.9土5.1, 扁平上皮癌19例 で21.5土5.1，その他 4 例 $16.0 \pm 8.2$ と各組織間
Fig. 7 Monocyte chemotactic response rate in patients with bronchogenic carcinoma; Related to clinical stage

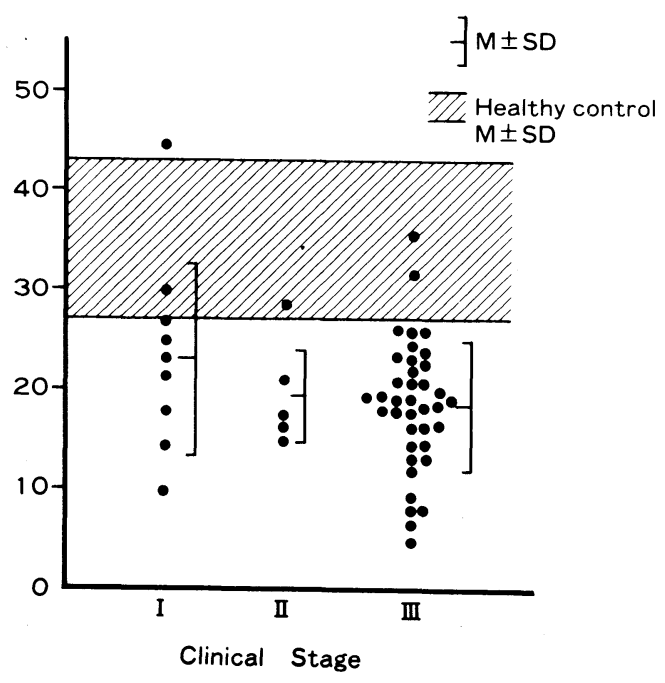

Fig. 8 Monocyte phagocytic index in patients with bronchogenic carcinoma and healthy controls

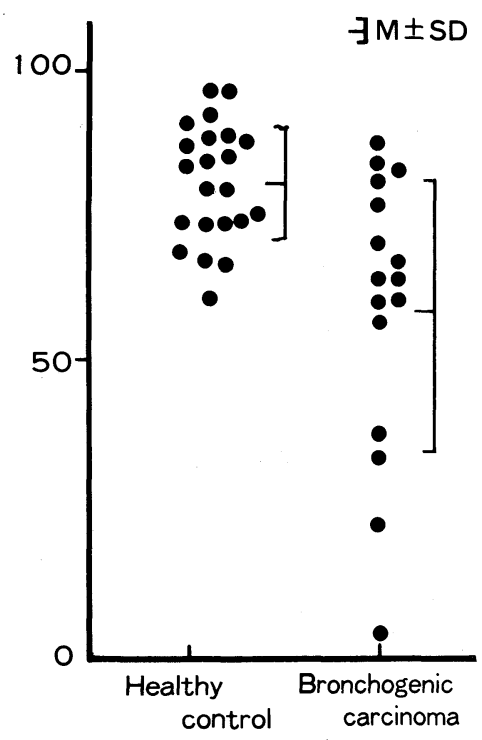

に有意の差は認めなかった。18例において化学 療法前と治療後 3 週間目の単球走性を比較した ところ，未治療時 $16.8 \pm 6.3 に$ 比して治療後は $12.9 \pm 4.3$ と有意の低下 $(\mathrm{P}<0.05)$ が認められた。 単球貧食能：肺癌患者 16 例の貧食指数は 60.8 \pm 23.6 で, 対照健康人 22 例の $82.1 \pm 9.5$ に比較し 
て有意な低下 $(\mathrm{P}<0.001)$ が認められた $($ 図 8$)$.

\section{考案}

末梢血に単球数の増加する疾患としては，従 来肺結核をはじめとする各種感染症, 造血器腫 瘍，血液疾患などがある. 5),6)しかし固型腫瘍に おける報告は少く, Barrett, O ? ’ らは悪性固型 腫瘍 100 例で, 健康人に比して平均值において有 意の増加を, Moldow, R. E. ${ }^{8)}$ らは膵癌220例中 $30 \%$ 単球数の増加例を，またMaldonado, J.

E. らは160例の単球增多症例中に, 卵巣癌, 胃 癌, 乳癌を含む13例の悪性固型腫瘍症例を報告 している。さらに実験動物においては，担癌う ツトで末梢血単球増多がみられ腫瘍を切除する と正常化し，転移をおこすと再び増加してくる

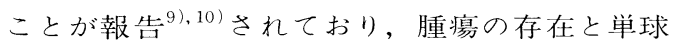
数の増加との関連性を窥わしめている。一方, 単球数の減少する疾患については, 従来の文献 には見当らない. 肺癌患者末梢血単球数は $294 \pm$ $176 / \mathrm{cmm}$ で, 対照健康人の $299 \pm 144 / \mathrm{cmm}$ に比 して全く差が認められなかった。病期別に比較 しても I， II 期症例はIII期症例よりも, やや減 少傾向がみられたのみであった。さらに各組織 型の間にも差はなかった。文献的にも肺癌患者 における単球数についての報告は見当らなかっ た。肺癌患者の末梢血単球数の抗癌剂による直 接的な影響を経過を追って検討したところ，抗 癌剂投与後 1 週目に激減し， 3 週目には治療前 の值に回復し, 4 週目には, overshootする症例も 多くみられた。同時に算定した末梢血白血球数， リンパ球数は 2 週目に最低值となり，4週目に ほぼ正常值に復した。即ち末梢血の単球は, 好 中球, リンパ球に比較して抗癌剂投与により速 やかに減少するが，回復も早いことが判明した。 化学療法による治療効果と末梢血単球数の変動 を比較検討したところ，化学療法を重ねてもな お単球数の回復が良好で増加のみられた症例に 治療効果の認められた症例が多かった。このこ とは単球の食菌, 殺菌作用が, 肺癌患者の感染 防止に作用し治療効果の向上に役立っているた めと考之られた。化学療法後に治療前よりも単 球数の増加を来した症例の存在したのは, 顆粒
球減少症に扔いて単球が相対的にも絶対的にも 増加する症例が報告されており, ‘抗癌剂により 続発性の顆粒球減少症を来し, そのために単球 増多を来したと都えられ，これら症例の骨髄細 胞の回復力の良好さを示していると思われた。

$\beta$-galactosidaseは単球の持つlysosomal enzymeの1つであり, 単球の活性化を示す指標 ${ }^{11), 12)}$ にな る. Rhades, J.M.S. ら ${ }^{12)}$ は腫瘍移植マウスの 腹㴏マクロファージは, 糖代謝の㠵進とともに 細胞内 $\beta$-galactosidase 活性の元進がみられ, マ クロファージのin vivoにおける活性化と細胞内 $\beta$ galactosidase活性它進とは正の相関を示すこと を報告している。今回の成績では肺癌患者の単 球 $\beta$-galactosidase 活性は健康人に比較して, 病 期，組織型の違いにかかわらず低下が認められ た。志摩 ${ }^{13 \prime} ら$ 同様に肺癌患者の単球 $\beta$-galactosidase 活性の低下傾向を報告している。この事 実は前述のRhodes, J.M.S. らの担癌動物にお ける成績と相反するものである。この違いは， 動物における移植腫瘍とちがって，七トにおけ る自然発生癌では腫瘍の発見された時点ですで に, 単球マクロフ.アージ采の疲弊を来している のではないかと考えられた。化学療法による影 響はほとんど受けなかった。

肺癌患者末梢血単球の走性は健康人のそれに 比して有意な低下がみられた。その低下はすべ ての病期，組織型においてみられた。文献的に も担癌患者に拈ける末梢血単球の走性の低下の 報告がみられる! 球走性の低下は子後不良の指標となる ${ }^{19)}$ こ, ま た手術にて腫瘍を取り除くと正常值に戻る症例

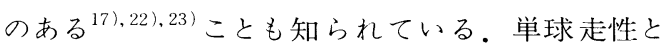
病期との関係については, 病期の進行とともに 低下するという報告と, ${ }^{181}$,21) 著者らの成績のごと く病期との相関を認めなかった報告 ${ }^{15)}$ がある、肺 癌に揖いては, Daughady, C.C. ら ${ }^{16)}$ は 5 例中 4 例に走性の低下を, Kay, A. B. ら ${ }^{18)}$ は31例 中，転移を伴う13例に低下を，手術可能な症例 では正常值であったとの報告がある。その他McVie, J. G. ${ }^{20)}$ Kjeldsberg, C. R. ${ }^{24)}$ 寻単球走性 低下を認めている。以上の成績から，肺癌患者 において未梢血単球走性の低下が存在すること 
は異論のないところであろ゙う。単球走性の低下 の原因としては, 担癌動物の血清中に走性を抑 制する物質の存在が証明され, 腫瘍が本物質を産 出していることが判明している?2),25) ヒトにおい ても21例の癌患者の $90 \% の$ 症例に血清中にMonocyte Chemotactic Factor Inactivatorが証明さ れ尕さらに腫瘍を切除すれば走性の正常化が認 められることなどより $2^{23), 24)}$ 動物におけると同様 に，ヒトにおいても腫瘍が単球走性を抑制する 物質を分泌していることが推测される。

担癌生体における網内系の貧食機能は, 炭素 ${ }^{26)}$ 粒子, 変性アルブミン27 脂肪乳剂 ${ }^{28)}$ な゙のクリ アランスを測定するin vivoでの方法が，もっぱ ら使用され，賓食機能立進が認吼ている。 しかし重症例では低下してい.る ${ }^{26)}$ 末梢血単球を 分離し，in vitroにおいて貧食能を検討した成績 は少い，著者らの成績では，肺癌患者の末梢血 単球の賽食能は健康人に比して有意に低下がみ

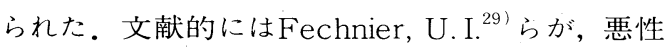
リンパ腫患者の重症例にIg G 結合七卜赤血球の 貿食能の低下を，一方ではKrebsforsh，Z.ら ${ }^{24)}$ は32例の末期腫瘍患者でYeastに対する貧食能 の充進を報告している。これらの相反する成績 の原因は，賓食される標的細胞の状態の違いに よるものと考えられる。即ち著者ら，Fechnier， U.I. らは，それぞれ標的細胞膜表面に補体，あ るいはIg Gを結合させており，単球膜上のそれ ぞれの受容体を介して附着, 貧食される免疫貧 食機能を検查したものであり，Krebsforsh, Z. らは無処置のYeastを使用した非特異的貧食能

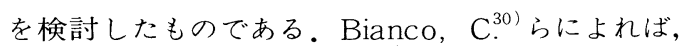
非活性化マクロファージは補体を結合した標的 細胞を，その膜面に附着するが貧食はしない， しかし活性化マクロファージは附着し,さらに貧
食をも行う。一方Ig Gを結合した標的細胞は活 性化，非活性化マクロファージをとわず附着し 筫食されると報告している。この事実からすれ ば著者らの得た肺癌患者における補体受容体を 介する貧食能の低下は，即ち活性化された単球 数の低下を示唆しているものと考えられ，前述 の $\beta$-galactosidase活性の低下と一致する成績と 考えられる。さらに肺癌患者の未梢血単球の膜 表面の補体受容体の量の減少のみられた症例电 あり ${ }^{16)}$ 補体結合Zymosanの貧食能の低下は単球 膜上の受容体の量的異常による可能性もある。

今回の著者らの成績をまとめてみると, 肺癌 患者に打ける末梢血単球は量的には健康人と比 して異常は認められなかった。しかし細胞内lysosomal enzymeの活性低下, 走性の低下, 貧食 能の低下と，いずれの機能にも低下が認められ， 単球の質的異常の存在が判明した。これらの事 実は担癌生体における腫瘍排除に対し，負の働 きをなしていることが推察される。これら単球 機能を抑制する原因としては, 患者血清中に単 球の走性をはじめとする機能を抑制する物質が, 腫瘍より分泌されているのではないかと考えら れた。

単球の機能不全と治療効果, 予後との関連性 を検討すると，化学療法にて一過性に量的減少 と走性の低下を来すが，質的に行われたすべて の検査に影響は受けなかった。従って又当然の こととして, 単球機能の異常の程度が軽いもの ほど, 尒後は良好であった。これは単球の直接 的な腫瘍傷害作用もさることながら，食菌作用 など感染防禦作用による感染症合併の予防によ り化学療法の継続が可能であることも良好な子 後に関係したものと考えられた。 
1) Shaw, G. M., Levy, P. C. and Lobuglio, A. F.: J. Immunol. $121:$ 573-578, 1978.

2) Mantovani, A., Jerrells, T. R., Dean, J. H. et al. Int. J. Cancer, $23: 18-27,1979$.

3) Rinehart, J. J. , Lange, P., Gormus, B. J. et al. : Blood, 52：211-220,1978.

4）木村郁郎, 守谷欣明, 中田安成他：肺癌 $18: 149-155,1978$.

5) Maldonado, J. E. and Hanlon, D. G. : Mayo Clin. Pro. 40:248-259, 1965.

6) Wintorbe, M. M. : The monocyte macrophage series. Clinical Hematology, Philadelphia, Lea \& Febiger, 1974.

7) Barrett, O. Jr.: Ann. Inter. Med. 73 : 991-992, 1970.

8) Moldow, R. E. : Ann. Inter. Med. $74: 449,1971$.

9) Eccles, S. A., Bandlow, G. and Alexander, P.: Br. J. Cancer, 34:20-27, 1976.

10) Normann, S. J., Schardt, M. and Sorkin, E. : Int. J. Cancer, $23: 110-113,1979$.

11) Karnovsky, M. L. and Lazdins, J. K. : J. Immunol. $121: 809-813,1978$.

12) Rhodes, J. M. , Bennedsen, J., Larsen, S. O., et al. Infect. Immunit. $23: 34-40,1979$.

13）志摩 清, 樋口定信, 岳中耐夫他: 癌の臨床 $21: 1308-1312,1975$.

14) Boetcher, D. A. and Leonard, E. J. : J. Natl. Cancer Inst. 52 : 1091-1099, 1974.

15) Hausman, M. S., Brosman, S., Snyderman, R., et al. J. Natl. Cancer Inst. $55:$ 1047-1054, 1975.

16) Daughaday, C. C., Schmidt, M.E. and Douglas,
S. D. : Am. Rev. Resp. Dis. 113：68, 1976.

17) Snyderman, R., Seigler.H.F. and Meadows, L. : J Natl. Cancer Inst. 58:37-41, 1977.

18) Kay, A. B. and McVie, J. G. : Br. J. Cancer, 36 : 461-466, 1977.

19) Snyderman, R. and Pike, M. C. : Am. J. Pathol. 88:727-740, 1977.

20) McVie, J. G. , Logan, E. C. M. and Kay, A. B. : Europ. J. Cancer, $13: 351-353$, 1977.

21) Leb, L. and Merritt, J. A. : Cancer, 41 : 17941803, 1978

22) Pasternack, G. R. P., Snyderman, R., Pike, M. C., et al. J. Exp. Med. 148:93-102,1978.

23) Snyderman, R., Meadows, L., Holder, W. et al.: J. Natl. Cancer Inst. 60:737-740,1978.

24) Kjeldsberg, C. R. and Pay, G. D. : Cancer. 41 : 2236-2241, 1978.

25) Pike, M. C. and Snyderman, R. : J. Immunol. $117: 1243-1249,1976$.

26) Old, L. J., Benacerraf, B., Clarke, D. A. , et al. Cancer Res. $21 ： 1281-1300,1961$.

27) Magarey, C. J. and Baum, M. : Brit. J. Surg. $57: 748-752,1970$.

28) Salky, N. K. , Di Luzio, N. R. , Levin. A. G. et al. : J. Lab. Clin. Med. $70 ： 393-403.1967$.

29) Fechnier, U. I. and Gross, R. : Klin. Wschr. 53 : 437-440, 1975.

30) Bianco, C. , Griffin, F. M. and Silverstein, S. C. J. Exp. Med. 141:1278-1290, 1975. 


\title{
Monocyte Function in Patients with Bronchogenic Carcinoma
}

\author{
Yasunari NAKATA, Mikio KATAOKA, Jiro YAMASHITA, Toshio SATO, \\ Norio NODA, Yasunori NAKATA, Shunkichi HIRAKI, \\ Taisuke OHONOSHI and Ikuro KIMURA
}

\author{
The Second Department of Internal Medicine, Okayama University \\ Medical School, Okayama 700, Japan \\ (Director: Professor Ikuro KIMURA)
}

\begin{abstract}
Function of peripheral blood monocyte in 59 untreated patients with bronchogenic carcinoma was studied and compared to that of normal controls. The total leukocyte count was determined with a Coulter counter, whereas the differential was determined on the basis of 500 cells counted. The absolute monocyte count was found by applying the percent of monocytes in the differential to the total leukocyte count. The mean absolute number of monocytes was $294 \pm 176 / \mathrm{cmm}$ in patients with bronchogenic carcinoma and $299 \pm 144 / \mathrm{cmm}$ in controls. However, there was no significant difference between these two groups. Furthermore monocyte number, clinical stage and histological type also failed to demonstrate any significant correlations among them.

Lysosomal enzyme activity of monocyte was histochemically determined by ability of staining to beta-galactosidase. The mean percentage of positive monocytes was $23.1 \pm 12.1$ in patients with bronchogenic carcinoma and $33.7 \pm 12.1$ in controls, which showed significant difference between these two groups.

Monocyte chemotactic response was measured in vitro by Boyden's millipore technique using zymosan activated human serum as chemoattractant. It was significantly reduced in bronchogenic carcinoma $(19.4 \pm 7.0)$ to compare with that of controls $(34.8 \pm 8.0)$. In addition, combination chemotherapy further reduced the monocyte chemotactic response rate.
\end{abstract}

Ability of monocytes to phagocytose complement fixing zymosan was also significantly lowered in patients with bronchogenic carcinoma.

These data suggested that neoplasm affect monocyte function which can possibly destruct malignant cells immunologically. 